\title{
Genetic parameters for noncoagulating milk, milk coagulation properties, and detailed milk composition in Swedish Red Dairy Cattle
}

\author{
S. I. Duchemin, ${ }^{1 *}$ K. Nilsson, ${ }^{2}$ W. F. Fikse,${ }^{3}$ H. Stålhammar, ${ }^{4}$ L. Buhelt Johansen, ${ }^{5}$ M. Stenholdt Hansen, ${ }^{5}$ \\ H. Lindmark-Månsson, ${ }^{2}$ D.-J. de Koning, ${ }^{1}$ M. Paulsson, ${ }^{2}$ and M. Glantz ${ }^{2}$ \\ ${ }^{1}$ Department of Animal Breeding and Genetics, Swedish University of Agricultural Sciences, PO Box 7023, SE-750 07 Uppsala, Sweden \\ ${ }^{2}$ Department of Food Technology, Engineering and Nutrition, Lund University, PO Box 124, SE-221 00, Lund, Sweden \\ ${ }^{3}$ Växa Sverige, PO Box 288, SE-751 05 Uppsala, Sweden \\ ${ }^{4}$ Viking Genetics, PO Box 64, SE-532 21, Skara, Sweden \\ ${ }^{5}$ Arla Foods amba, Agro Food Park 19, DK-8200 Aarhus N, Denmark
}

\section{ABSTRACT}

The rennet-induced coagulation ability of milk is important in cheese production. For Swedish Red Dairy Cattle (RDC), this ability is reduced because of a high prevalence of noncoagulating (NC) milk. In this study, we simultaneously combined genetic parameters for NC milk, milk coagulation properties, milk composition, physical traits, and milk protein composition. Our aim was to estimate heritability and genetic and phenotypic correlations for NC milk and 24 traits (milk coagulation properties, milk composition, physical traits, and milk protein composition). Phenotypes and $\sim 7,000$ SNP genotypes were available for all 600 Swedish RDC. The genotypes were imputed from $\sim 7,000$ SNP to 50,000 SNP. Variance components and genetic parameters were estimated with an animal model. In Swedish RDC, a moderate heritability estimate of 0.28 was found for NC milk. For the other 24 traits, heritability estimates ranged from 0.12 to 0.77 (standard errors from 0.08 to 0.18 ). A total of 300 phenotypic and genetic correlations were estimated. For phenotypic and genetic correlations, 172 and 95 were significant, respectively. In general, most traits showing significant genetic correlations also showed significant phenotypic correlations. In this study, phenotypic and genetic correlations with $\mathrm{NC}$ milk suggest that many correlations between traits exist, making it difficult to predict the real consequences on the composition of milk, if selective breeding is applied on NC milk. We speculate that some of these consequences may lead to changes in the composition of milk, most likely affecting its physical and organoleptic properties. However, our results suggest that $\kappa$-casein could be used as an indicator trait to predict the occurrence of $\mathrm{NC}$ milk at the herd level.

Received February 4, 2020.

Accepted April 21, 2020.

*Corresponding author: sandrine.duchemin@slu.se
Key words: noncoagulating milk, milk coagulation, heritability, genetic correlation, genetic parameter

\section{INTRODUCTION}

The rennet-induced coagulation ability of milk is important for cheese production. For Swedish Red Dairy Cattle (RDC), this ability is reduced because of a high prevalence of cows producing noncoagulating (NC) milk. For Swedish RDC, Gustavsson et al. (2014c) estimated a prevalence of NC milk of $18 \%$. Nilsson et al. (2019) confirmed these findings in a larger sample set, showing that the occurrence of NC milk (18\%) and poorly coagulating milk (19\%) summed to $37 \%$ for Swedish RDC. Furthermore, genetic exchange between Swedish RDC and other red breeds across Europe and Canada exists, which may contribute to increase the problem of NC milk worldwide. Thus, research done on Swedish RDC may be beneficial for the cheese production industry in Sweden but also in countries where RDC cows are used or RDC semen is used for crossbreeding.

It is well established that NC milk is present in breeds other than Swedish RDC. For example, the prevalence of NC milk was reported by Ikonen et al. (2004) in Finnish Ayrshires (13.3\%); by Cecchinato et al. (2011) in Italian Holsteins (9.7\%) and Brown Swiss (3.5\%); and by Poulsen et al. (2015) in Danish Holsteins (4.8\%). Therefore, the occurrence of NC milk in breeds other than reds suggest that the NC milk problem has been overlooked in many breeds worldwide.

Good milk coagulation properties are necessary for cheese production. Milk coagulation properties are influenced by genetic and environmental factors, as previously reviewed by Bittante et al. (2012). In brief, milk coagulation properties are influenced by breed (e.g., Bittante et al., 2012), SCC (e.g., Cassandro et al., 2008), milk protein composition (e.g., Tervala et al., 1983), casein composition (e.g., Okigbo et al., 1985), 
and stage of lactation (e.g., Tyrisevä et al., 2004), among other factors. Milk coagulation properties are heritable according to Ikonen et al. (2004) and could be improved by selective breeding. The difficulty with milk coagulation properties lies in obtaining a phenotype in a routine, timely manner and at low-cost. Milk coagulation properties are measured on individual cows, which complicates the collection of reliable phenotypes in sufficient numbers to enable selective breeding against NC milk. Therefore, an alternative approach could be to improve traits that favorably correlate with milk coagulation properties.

Determining which traits simultaneously can improve milk coagulation properties and reduce NC milk is not an easy task, because the mechanism causing NC milk is still unclear. Many studies have studied the genetic parameters of milk coagulation properties versus production traits, metabolites, and minerals alone (e.g., Ikonen et al., 2004; Buitenhuis et al., 2013, 2015; Gustavsson et al., 2014c). Other studies have simply removed NC milk from milk coagulation properties before estimating genetic parameters. However, studies combining genetic parameters for NC milk, milk coagulation properties, milk composition, physical traits, and milk protein composition simultaneously are scarce. Therefore, the aim of this study was to estimate genetic parameters for NC milk and 24 traits (milk coagulation properties, milk composition, physical traits, and milk protein composition), which were all measured on 600 Swedish RDC. We estimated heritability and genetic and phenotypic correlations and provided breeding perspectives against NC milk while improving milk coagulation properties.

\section{MATERIALS AND METHODS}

\section{Sampling}

Blood and milk samples from Swedish RDC were collected from 31 conventional herds in the south of Sweden. Cows with both phenotypes and genotypes available were included in the present study, resulting in 600 individual cows. Sampling occurred from December 2015 to April 2016 and from September 2016 to April 2017, corresponding to periods when cows were stabled. Cows were milked twice a day and fed according to standard practices. Cows were ranging from parity 1 to 8, and each cow was between 63 and $282 \mathrm{~d}$ in lactation. Each cow was sampled once during morning milking. All farms were sampled once, except for one large herd that was sampled 3 times. All of the milk samples had an SCC $<300,000$ cells $/ \mathrm{mL}$. Milk was collected, cooled, and transported to Lund University (Lund, Sweden) on the day of milking. The samples were kept at $7^{\circ} \mathrm{C}$ or frozen at $-18^{\circ} \mathrm{C}$ until further analyses. Skim milk was obtained by centrifugation at $2,000 \times g$ at $4^{\circ} \mathrm{C}$ for 30 min (Allergra X-15R Centrifuge, Beckman Coulter, Brea, CA).

\section{Phenotypes}

Milk Composition and Physical Traits. Analyses for fat, protein, lactose, and calcium contents as well as for SCC were done on fresh whole milk by a certified dairy laboratory (Eurofins Steins Laboratorium $\mathrm{AB}$, Jönköping, Sweden). Briefly, fat, protein, and lactose contents were measured using a Fourier transform infrared spectroscopy. Calcium content was determined using inductively coupled plasma atomic emission spectroscopy, and SCC was determined using flow cytometry.

The analyses for $\mathrm{pH}$, ionic calcium concentration, and casein micelle size were done on fresh skim milk as described by Nilsson et al. (2019). The pH was measured using a $\mathrm{pH}$ meter at ambient temperature. Ionic calcium $\left(\mathrm{Ca}^{2+}\right)$ concentration was analyzed using an ion selective electrode (9720BNWP, Thermo Fisher Scientific, Waltham, MA) at $32^{\circ} \mathrm{C}$. Casein micelle size was measured using laser light scattering (Mastersizer 2000, Malvern Instruments, Malvern, UK).

The remaining analyses for casein content, citric acid content, and the milk protein individual fractions were done on frozen whole milk as described by Nilsson et al. (2019). Casein and citric acid contents were determined using Fourier transform infrared spectroscopy. The relative concentrations of $\alpha$-LA, $\beta-\mathrm{LG}, \alpha_{\mathrm{S}_{1}} \mathrm{CN}, \alpha_{\mathrm{S} 2}-\mathrm{CN}, \beta-\mathrm{CN}$, and $\kappa-\mathrm{CN}$ were obtained by liquid chromatography-high resolution mass spectrometry (LC-HRMS), as follows: $200 \mu \mathrm{L}$ of frozen whole milk was thawed and reduced for $60 \mathrm{~min}$ in 20 $\mu \mathrm{L}$ of dithioerythritol (0.5 M; Sigma-Aldrich, St. Louis, $\mathrm{MO})$, together with $1 \mathrm{~mL}$ of the buffer with urea $(6 \mathrm{M}$; Sigma-Aldrich) and trisodium citrate $(100 \mathrm{~m} M$; Merck, Darmstadt, Germany) at $30^{\circ} \mathrm{C}$. The samples were then centrifuged at $16,100 \times g$ and $5^{\circ} \mathrm{C}$ for $10 \mathrm{~min}$, and $5 \mu \mathrm{L}$ of the supernatant was injected into the 1290 LC coupled to a 6230 HRMS (Agilent Technologies, Santa Clara, CA) using a Poroshell 120 SB-C18 2.1 $\times 150 \mathrm{~mm}, 2.7 \mu \mathrm{m}$ (Agilent Technologies) column at $40^{\circ} \mathrm{C}$, where the UV detection was at $214 \mathrm{~nm}$. The LCHRMS method was adapted from Rauh et al. (2015). A gradient of buffer A $0.05 \%$ (vol/vol) trifluoroacetic acid (TFA; Thermo Fisher Scientific, Waltham, MA) in deionized water and buffer B $0.1 \%$ (vol/vol) TFA in acetonitrile (Rathburn, Walkerburn, UK) was used to separate casein and whey proteins. The gradient had the following composition: $15 \%$ buffer B at $1 \mathrm{~min}, 34 \%$ buffer B at 4 min, and $47 \%$ buffer B at 19 min. Data of 
the UV chromatograms were analyzed by MassHunter (version B 7) and Profinder (prerelease version B.08.00 Service Pack 1) software (Agilent Technologies). The relative concentration of each protein was obtained by dividing the integrated peak area for a protein with the integrated total peak area for that sample. The sum of whey proteins was calculated as the sum of $\alpha$-LA and $\beta-\mathrm{LG}$ contents, whereas the sum of $\mathrm{CN}$ was calculated as the sum of $\alpha_{\mathrm{S}^{-}} \mathrm{CN}, \alpha_{\mathrm{S}_{2}} \mathrm{CN}, \beta-\mathrm{CN}$, and $\kappa-\mathrm{CN}$ contents. Only samples with less than 10\% degraded proteins were included in the study. Further details on the milk samples can be found in Nilsson et al. (2019).

Rennet-Induced Coagulation. Milk coagulation properties were determined on all samples after rennet addition to skim milk using free oscillation rheometry (ReoRox4, MediRox AB, Nyköping, Sweden; rox). Additionally, low-amplitude rheometry (StressTech, ReoLogica Instruments AB, Lund, Sweden; hereafter, "stress") was used on randomly selected samples. The coagulation analyses were performed as described in Nilsson et al. (2019). The coagulation was followed at $32^{\circ} \mathrm{C}$ for 40 min, where skim milk samples were adjusted to $\mathrm{pH} 6.5$ before addition of chymosin [0.09 international milk clotting units (IMCU)/mL milk; Chy-Max Plus, $200 \mathrm{IMCU} / \mathrm{mL}$, Chr. Hansen A/S, Hørsholm, Denmark]. During the recording, rennet coagulation times $\left(\mathbf{R C} \mathbf{T}_{\text {rox }}\right.$ and $\mathbf{R C} \mathbf{T}_{\text {stress }}$ ), rate of gel formation (curd forming rate, $\left.\mathbf{C F} \mathbf{R}_{\text {rox }}\right)$, gel strengths $\left(\mathbf{G}_{\text {rox }}^{\prime}\right.$ and $\left.\mathbf{G}^{\prime}{ }_{\text {stress }}\right)$, and yield stress ( $\left.\boldsymbol{\sigma}_{\mathbf{y} \_s t r e s s}\right)$ were obtained from the 2 rheometer systems (rox and stress). The coagulation properties were defined as follows: $\mathrm{RCT}_{\text {rox }}$ was the time to reach a phase angle of $45^{\circ}, \mathrm{RCT}_{\text {stress }}$ was the time when the gel strength increased continuously, $\mathrm{CFR}_{\text {rox }}$ was the rate of gel formation between $\mathrm{RCT}_{\text {rox }}$ and the end of the measurement, $G^{\prime}$ rox was the highest gel strength during the recording, $\mathrm{G}_{\text {stress }}^{\prime}$ was the gel strength after $40 \mathrm{~min}$, and $\sigma_{\text {y_stress }}$ was the shear stress at $90 \%$ of maximum viscosity. Samples with an $\mathrm{RCT}_{\text {rox }}$ $\geq 40$ min were defined as NC. Descriptive statistics for NC milk, milk coagulation properties, milk composition and physical traits, and milk protein composition can be found in Table 1 .

Table 1. Descriptive statistics for noncoagulating (NC) milk, milk coagulation properties, milk composition and physical traits, and milk protein composition

\begin{tabular}{|c|c|c|c|c|c|}
\hline Trait $^{1}$ & Observations & Mean & $\mathrm{SD}$ & $\mathrm{CV}$ & $\operatorname{Var}(\text { herd })^{2}$ \\
\hline NC milk & 116 & 0.19 & 0.40 & 2.04 & $3.40 \mathrm{E}-03$ \\
\hline \multicolumn{6}{|l|}{ Milk coagulation properties } \\
\hline $\mathrm{CFR}_{\text {rox }}(\mathrm{Pa} / \mathrm{min})$ & 600 & 0.13 & 2.32 & 17.85 & 0.24 \\
\hline $\mathrm{RCT}_{\text {rox }}(\min )$ & 600 & 19.39 & 13.56 & 0.70 & 5.35 \\
\hline $\mathrm{G}_{\text {rox }}^{\prime}(\mathrm{Pa})$ & 600 & 14.56 & 9.26 & 0.64 & 4.34 \\
\hline $\mathrm{G}_{\text {stress }}^{\prime}(\mathrm{Pa})$ & 285 & 128.80 & 74.99 & 0.58 & 494.85 \\
\hline $\mathrm{RCT}_{\text {stress }}(\min )$ & 285 & 9.69 & 9.43 & 0.97 & 3.33 \\
\hline$\sigma_{\mathrm{y} \_ \text {stress }}(\mathrm{Pa})$ & 285 & 17.25 & 8.22 & 0.48 & 9.30 \\
\hline \multicolumn{6}{|l|}{ Milk composition and physical traits } \\
\hline Fat $(\%)$ & 600 & 4.46 & 1.57 & 0.35 & 0.35 \\
\hline Protein (\%) & 600 & 3.65 & 0.36 & 0.10 & $1.67 \mathrm{E}-02$ \\
\hline Lactose (\%) & 600 & 4.63 & 0.22 & 0.05 & $9.79 \mathrm{E}-03$ \\
\hline $\operatorname{SCC}(1,000$ cells $/ \mathrm{mL})$ & 600 & 1.53 & 0.40 & 0.26 & $1.19 \mathrm{E}-02$ \\
\hline Calcium $(\mathrm{mg} / \mathrm{kg})$ & 600 & $1,235.00$ & 200.50 & 0.16 & $9,783.93$ \\
\hline $\mathrm{Ca}^{2+}(\mathrm{mmol} / \mathrm{L})$ & 354 & 2.64 & 0.71 & 0.27 & 0.50 \\
\hline Citric acid (\%) & 577 & 0.19 & 0.03 & 0.17 & $2.82 \mathrm{E}-04$ \\
\hline $\mathrm{pH}$ & 600 & 6.69 & 0.08 & 0.01 & $2.14 \mathrm{E}-03$ \\
\hline $\mathrm{CN}$ micelle size $(\mu \mathrm{m})$ & 534 & 0.14 & 0.02 & 0.14 & $5.88 \mathrm{E}-05$ \\
\hline \multicolumn{6}{|l|}{ Milk protein composition } \\
\hline $\mathrm{CN}(\%$ in milk $)$ & 577 & 2.86 & 0.31 & 0.11 & $1.30 \mathrm{E}-02$ \\
\hline$\alpha-\mathrm{LA}\left(\%\right.$ of $\left.\mathrm{TP}^{3}\right)$ & 543 & 3.22 & 0.50 & 0.16 & $5.07 \mathrm{E}-02$ \\
\hline$\beta-\mathrm{LG}(\%$ of TP) & 543 & 8.38 & 1.35 & 0.16 & 0.21 \\
\hline Sum of whey proteins ( $\%$ of TP) & 543 & 11.60 & 1.34 & 0.12 & 0.30 \\
\hline$\alpha_{\mathrm{S}^{-}-} \mathrm{CN}(\%$ of TP $)$ & 543 & 27.85 & 1.69 & 0.06 & 0.76 \\
\hline$\alpha_{\mathrm{S}_{2}}-\mathrm{CN}(\%$ of TP) & 543 & 9.19 & 1.16 & 0.13 & 0.55 \\
\hline$\beta-\mathrm{CN}(\%$ of $\mathrm{TP})$ & 543 & 34.31 & 1.79 & 0.05 & 0.88 \\
\hline$\kappa-\mathrm{CN}(\%$ of TP) & 543 & 11.47 & 1.39 & 0.12 & 0.25 \\
\hline Sum of CN (\% of TP) & 543 & 82.83 & 1.87 & 0.02 & 0.59 \\
\hline
\end{tabular}

${ }^{1} \mathrm{NC}=$ noncoagulating milk; in total, 116 samples were $\mathrm{NC}$ and 484 samples were well-coagulated milk. CFR $=$ curd firming rate; $\mathrm{RCT}=$ rennet coagulation time; $\mathrm{G}^{\prime}=$ gel strength; $\sigma_{\mathrm{y} \text { stress }}=$ yield stress. Rox or stress refers to the rheometric system used, free oscillation or low-amplitude oscillation, respectively. Measurements for SCC are log-transformed, and measurements for $\mathrm{CFR}_{\text {rox }}$ and $\mathrm{G}_{\text {rox }}^{\prime}$ are Box-Cox-transformed. Four outliers were removed from calcium content.

${ }^{2} \operatorname{Var}($ herd) is the herd variance.

${ }^{3}$ Total protein. 


\section{Genotypes and Imputation}

For genotyping purposes, DNA was extracted from blood samples and the cows were genotyped for lowdensity SNP chip of 6,990 SNP (LDSNP; Infinium Bovine LD BeadChip from Illumina Inc., San Diego, CA). In addition, Nordic Cattle Genetic Evaluation (NAV) provided imputed medium-density SNP chip of 50,000 SNP (MDSNP) genotypes that were obtained by imputing genotypes from LDSNP to MDSNP based on a large reference population of genotyped animals (more than 50,000). This imputation was based on tens of thousands of genotyped bulls that include the sires of most, if not all, cows in the study. Quality controls of imputed MDSNP were performed by NAV following standard practices (e.g., exclusion of monomorphic SNP; exclusion of SNP with minor allele frequency $<1 \%$; and a minimum of $95 \%$ of nonmissing SNP per called genotype). All SNP without a map position on the UMD 3.1 genome assembly (Zimin et al., 2009) as well as the sex chromosomes were discarded. After edits, NAV's imputed MDSNP consisted of 45,618 SNP spread across 29 chromosomes. Imputation from LDSNP to MDSNP was done using Fimpute version 2.2 (Sargolzaei et al., 2014), and resulted in a total of 600 animals with imputed MDSNP genotypes.

\section{Statistical Analyses}

Variance components and genetic parameters were estimated in ASReml version 4.1 (Gilmour et al., 2015) with the following animal model (Eq. [1]):

$$
\begin{aligned}
y_{i j l m}= & \mu+\text { parity }_{i}+\text { wim }_{i j l m}+e^{\left(-0.05 \times \text { wim }_{i j l m}\right)} \\
& + \text { animal }_{l}+\text { herd }_{m}+e_{i j l m}
\end{aligned}
$$

where $y_{i j l m}$ is the observation of the trait of interest; $\mu$ is the overall mean; parity $_{i}$ is the fixed effect of parturition $(i=1,2,3)$, where parities 3 to 8 were grouped together; wim $_{i j l m}$ is a covariate describing the effect of weeks in lactation $(j=1.4$ to 66.9$)$, modeled with a Wilmink curve (Wilmink, 1987); animal is the random additive genetic effect assumed to be distributed as $N \sim\left(0, \mathbf{G} \sigma_{a}^{2}\right)$, where $\mathbf{G}$ is the genomic relationship matrix based on 600 cows with imputed MDSNP genotypes and $\sigma_{a}^{2}$ is the genetic variance. The $\mathbf{G}$ matrix was built as described by Van Raden (2008). herd ${ }_{m}$ is the random herd effect assumed to be distributed as $N \sim\left(0, \mathbf{I} \sigma_{\text {herd }}^{2}\right)$, where $\mathbf{I}$ is the identity matrix and $\sigma_{\text {herd }}^{2}$ is the herd variance; and $e_{i j l m}$ is the random residual effect assumed to be distributed as $N \sim\left(0, \mathbf{I} \sigma_{e}^{2}\right)$, where I is the identity matrix and $\sigma_{e}^{2}$ is the residual variance.

After applying Eq. [1], SCC was log-transformed, $\mathrm{CFR}_{\text {rox }}$ and $\mathrm{G}_{\text {rox }}^{\prime}$ were Box-Cox-transformed, and 4 outliers were removed from calcium content.

Intraherd heritability estimates were calculated according to Eq. [2]:

$$
h^{2}=\frac{\sigma_{a}^{2}}{\sigma_{a}^{2}+\sigma_{e}^{2}} .
$$

Phenotypic $\left(\boldsymbol{r}_{p}\right)$ and genetic $\left(\boldsymbol{r}_{g}\right)$ correlations between traits $(i \times j)$ measured in this study were estimated by bivariate analyses using Eq. [1]. The correlations were calculated using Eq. [3]:

$$
r_{p} \text { or } r_{g}=\frac{\text { Covariance }(i, j)}{\left(\sqrt{\sigma_{i}^{2} \times \sigma_{j}^{2}}\right)}
$$

Significance levels of phenotypic and genetic correlations were assessed as deviations of $>1.96 \times \mathrm{SE}$ from zero $(P<0.025)$ and as deviations of $>1.645 \times \mathrm{SE}$ from zero $(P<0.05)$.

\section{RESULTS}

\section{Descriptive Statistics}

Phenotypic means and coefficients of variation $(\mathbf{C V})$ of the 25 studied traits are presented in Table 1. Among the 600 samples, $19 \%$ of the cows produced NC milk. The phenotypic means of milk composition traits, physical traits, and milk protein composition are in agreement with previous studies on the Swedish RDC (Hallén et al., 2008; Gustavsson et al., 2014a,c). In general, $\mathrm{CV}$ were much higher for milk coagulation properties than for milk composition, physical traits, and milk protein composition (Table 1).

\section{Heritability Estimates}

Heritability estimates of the 25 studied traits ranged from 0.12 to 0.77 (SE from 0.08 to 0.18; Figure 1). For $\mathrm{NC}$ milk, significant moderate heritability was found $\left(\mathrm{h}^{2}\right.$ $=0.28)$. For milk coagulation properties, heritability estimates, obtained from 2 different rheological systems, were moderate to high, ranging from $0.32\left(\mathrm{RCT}_{\text {stress }}\right)$ to $0.56\left(\mathrm{G}_{\text {stress }}^{\prime}\right)$. Conversely, heritability estimates were moderate, ranging from 0.32 for $\mathrm{RCT}_{\text {stress }}$ to 0.42 for 


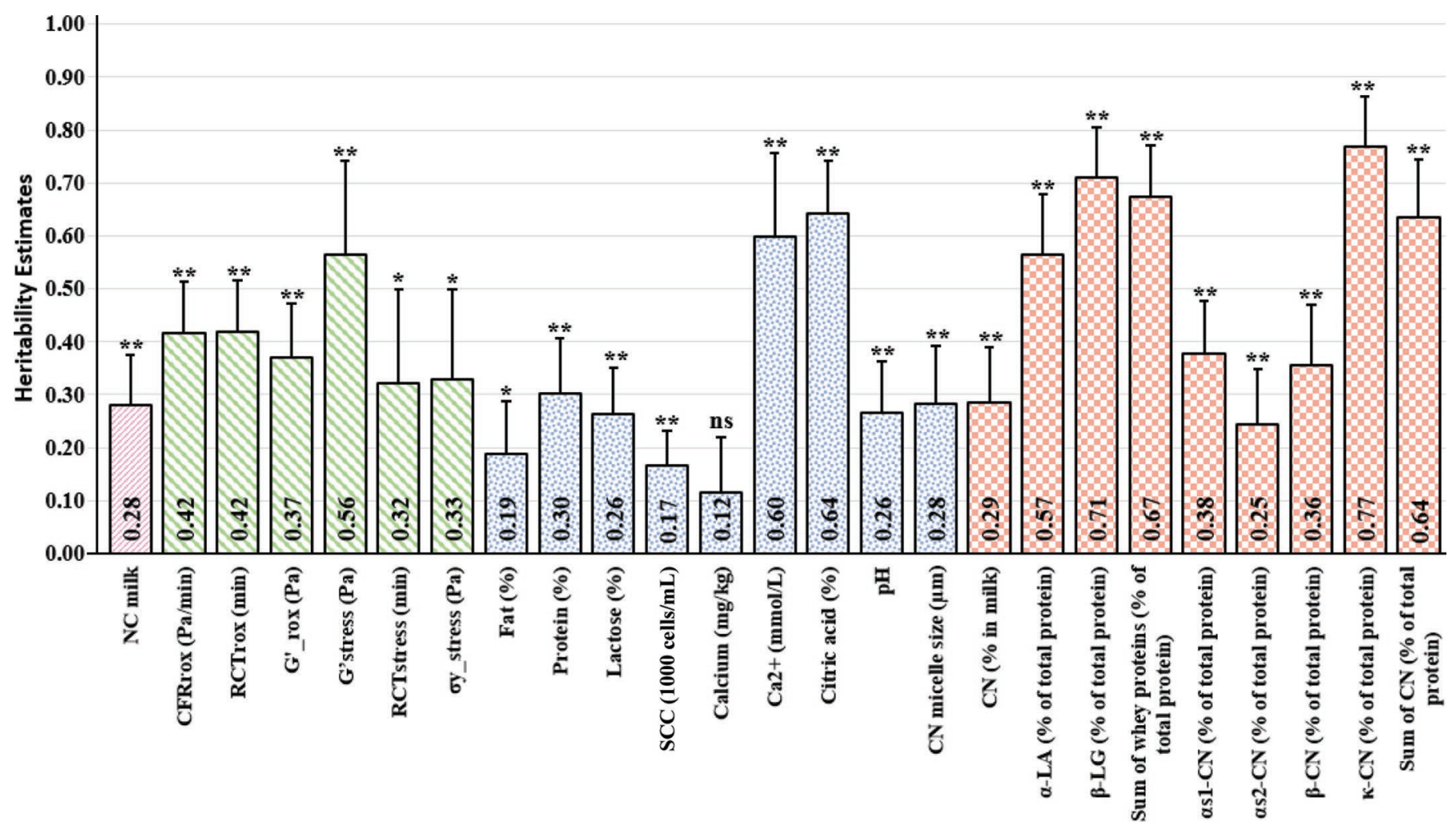

Figure 1. Heritability estimates for noncoagulating (NC) milk, milk coagulation properties, milk composition and physical traits, and milk protein composition. Error bars indicate standard errors (SE); significance levels at ${ }^{*} P<0.05,{ }^{* *} P<0.025$, and ns $(P>0.05)$. CFR $=$ curd firming rate; $\mathrm{RCT}=$ rennet coagulation time; $\mathrm{G}^{\prime}=$ gel strength; $\sigma_{\mathrm{y}_{-} \text {stress }}=$ yield stress; rox or stress refers to the rheometric system used: free oscillation or low-amplitude oscillation, respectively. Measurements for SCC are log-transformed and measurements for CFRrox and G'rox are Box-Cox-transformed. Four outliers were removed from calcium content.

$\mathrm{RCT}_{\text {rox }}$. For milk composition and physical traits, low to moderate heritability estimates were found, except for citric acid content and ionic calcium, both with heritability estimates $\geq 0.60$. For milk protein composition, heritability estimates $\geq 0.57$ were found for $\kappa$-CN content, $\beta$-LG content, sum of whey proteins, sum of $\mathrm{CN}$, and $\alpha$-LA content. Furthermore, moderate heritability estimates ranging from 0.29 to 0.38 were found for the remaining milk protein composition traits.

\section{Phenotypic and Genetic Correlations}

A total of 300 phenotypic and genetic correlations were estimated (Table 2). Of the phenotypic correlations, 158 were significant at $P<0.025$ and 14 more were significant at $P<0.05$, whereas for genetic correlations, 78 were significant at $P<0.025$ and 17 more were significant at $P<0.05$. In general, most traits with significant genetic correlations also had significant phenotypic correlations (Table 2). However, this was not the case for 6 correlations: between (1) $\mathrm{NC}$ and $\alpha_{\mathrm{S}_{2}} \mathrm{CN}$ content; (2) $\mathrm{RCT}_{\text {stress }}$ and fat content; (3) $\mathrm{CFR}_{\text {rox }}$ and citric acid content; (4) fat content and casein micelle size; (5) $\sigma_{\mathrm{y}_{-} \text {stress }}$ and $\alpha_{\mathrm{S}_{2}} \mathrm{CN}$ content; and (6) $\mathrm{RCT}_{\text {rox }}$ and $\alpha_{\mathrm{S}^{2}} \mathrm{CN}$ content.

NC Milk. In Table 2, NC milk was negatively correlated with most of the milk coagulation properties, except for $\mathrm{RCT}_{\text {stress }}\left(r_{p}=0.83 ; r_{g}=0.99\right)$. For the remaining milk coagulation properties, correlations were significant at $P<0.025$ and ranged from -0.87 to -0.64 for phenotypic correlations and from -1.00 to -0.83 for genetic correlations. For compositional traits, NC milk showed negative phenotypic correlations with fat and calcium contents as well as with ionic calcium, and showed negative genetic correlation with calcium content $\left(r_{g}=-0.96\right)$. For milk protein composition, $\mathrm{NC}$ milk showed positive phenotypic correlations with $\alpha-\mathrm{LA}$ and $\beta-\mathrm{CN}$ contents, and negative phenotypic correlations with $\beta-\mathrm{LG}$ and $\kappa-\mathrm{CN}$ contents. Noncoagulating milk showed positive genetic correlations with $\alpha$-LA and $\alpha_{\mathrm{S}_{2}} \mathrm{CN}$ contents, and a negative genetic correlation with $\kappa$-CN content. Although phenotypic correlations between NC milk and milk protein composition traits ranged from low to moderate, genetic correlations between NC milk and milk protein composition traits ranged from moderate to high. 


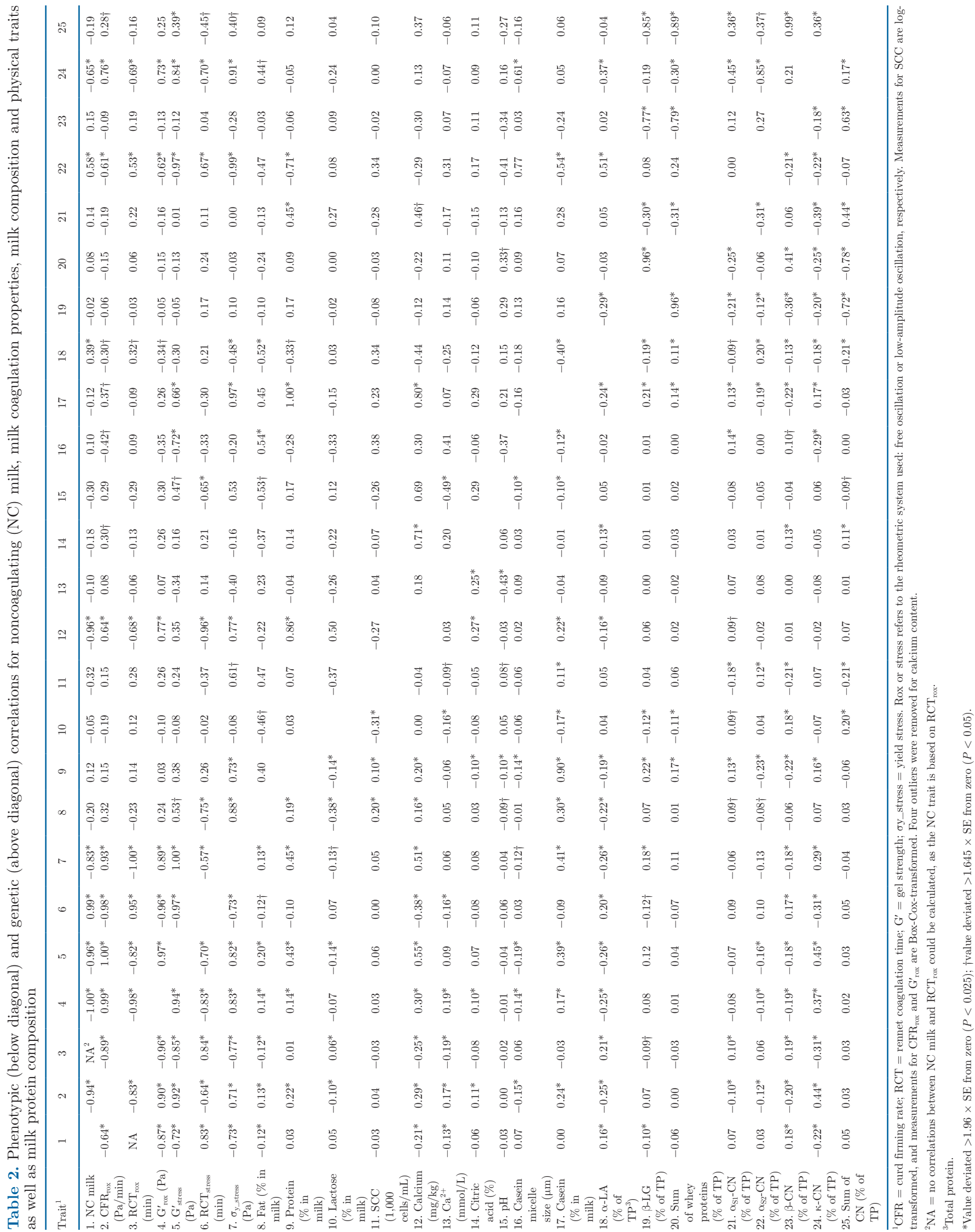


Milk Coagulation Properties. Among milk coagulation properties, correlations were moderate to high and genetic correlations were stronger than phenotypic correlations (Table 2). Furthermore, phenotypic correlations were weaker than genetic correlations between milk coagulation traits and milk compositional traits at $P<0.025$ ( $r_{p}$ ranging from -0.38 to $0.55 ; r_{g}$ ranging from -0.96 to 1.00$)$. Calcium content was phenotypically and genetically correlated with all milk coagulation traits $\left(r_{p}\right.$ ranging from -0.38 to $0.55 ; r_{g}$ ranging from -0.96 to 0.77 ), except for genetically with $\mathrm{G}_{\text {stress }}$. Ionic calcium had a significant phenotypic correlation with all milk coagulation traits except for $\mathrm{G}_{\text {stress }}^{\prime}$ and $\sigma_{\mathrm{y}_{\text {_stress }}}$; however, no significant genetic correlations were found. Between milk coagulation properties and milk protein composition, phenotypic correlations ranged from -0.31 to 0.45 , and genetic correlations ranged from -0.99 to 0.97 . Contents of $\kappa-\mathrm{CN}$ and $\alpha$-LA had significant phenotypic and genetic correlations with many of the milk coagulation traits $\left(r_{p}\right.$ ranging from -0.31 to $0.44 ; r_{g}$ ranging from -0.70 to 0.91$)$. Furthermore, $\beta$-CN content had significant phenotypic correlations with all milk coagulation properties, whereas $\beta$-LG content had a significant phenotypic correlation only with $\sigma_{y_{-} \text {stress }}$. Additionally, $\alpha_{\mathrm{S}^{2}} \mathrm{CN}$ content had significant genetic correlations with all milk coagulation properties (Table 2).

Milk Composition, Physical Traits, and Protein Composition. Among these traits, contents of calcium, $\alpha-\mathrm{LA}, \kappa-\mathrm{CN}$, and $\alpha_{\mathrm{S}_{2}} \mathrm{CN}$ had both significant genetic and phenotypic correlations with NC milk. These traits were further investigated to predict effects of breeding against NC milk. For instance, calcium content had significant phenotypic and genetic correlations with contents of protein $\left(r_{p}=0.20 ; \mathrm{r}_{\mathrm{g}}=0.86\right)$, citric acid $\left(r_{p}=0.27 ; r_{g}=0.71\right)$, and casein $\left(r_{p}=0.22 ; \mathrm{r}_{\mathrm{g}}\right.$ $=0.80)$. Moreover, calcium content had a significant phenotypic correlation with fat content $\left(r_{p}=0.16\right)$ and $\alpha$-LA $\left(r_{p}=-0.16\right)$. Content of $\alpha$-LA had significant phenotypic and genetic correlations with contents of fat $\left(r_{p}=-0.22 ; r_{g}=-0.52\right)$, casein $\left(r_{p}=-0.24 ; r_{g}=\right.$ $-0.40), \beta-\mathrm{LG}\left(r_{p}=-0.19 ; r_{g}=-0.29\right), \alpha_{\mathrm{S} 2} \mathrm{CN}\left(r_{p}=\right.$ $\left.0.20 ; r_{g}=0.51\right)$, and $\kappa-\mathrm{CN}\left(r_{p}=-0.18 ; r_{g}=-0.37\right)$. Moreover, $\alpha$-LA had significant phenotypic correlations with contents of protein $\left(r_{p}=-0.19\right)$, citric acid $\left(r_{p}\right.$ $=-0.13)$, and $\beta-\mathrm{CN}\left(r_{p}=-0.13\right)$ as well as the sum of CN $\left(r_{p}=-0.21\right)$ and whey proteins $\left(r_{p}=0.11\right)$. $\kappa$-Casein content had significant phenotypic and genetic correlations with contents of $\alpha_{\mathrm{S} 1} \mathrm{CN}\left(r_{p}=-0.39\right.$; $\left.r_{g}=-0.45\right), \alpha_{S 2}$ CN $\left(r_{p}=-0.22 ; r_{g}=-0.85\right)$, sum of CN $\left(r_{p}=0.17 ; r_{g}=0.36\right)$, and sum of whey proteins $\left(r_{p}=-0.25 ; r_{g}=-0.30\right)$ as well as casein micelle size $\left(r_{p}=-0.29 ; r_{g}=-0.61\right)$. Furthermore, $\kappa$-CN content had significant phenotypic correlations with contents of protein $\left(r_{p}=0.16\right)$, casein $\left(r_{p}=+0.17\right), \beta$-LG $\left(r_{p}=\right.$ $-0.20)$, and $\beta-\mathrm{CN}\left(r_{p}=-0.18\right)$. Finally, $\alpha_{\mathrm{S}_{2}} \mathrm{CN}$ content had significant genetic correlations with contents of protein $\left(r_{g}=-0.71\right)$ and casein $\left(r_{g}=-0.54\right)$.

\section{DISCUSSION}

In this study, we estimated the genetic parameters for NC milk, milk coagulation properties, milk composition and physical traits, and milk protein composition in Swedish RDC. A similar study was conducted by Gustavsson et al. (2014c), who gave insightful information about NC milk and how selective breeding could be used to reduce the prevalence of NC milk. Based on Gustavsson et al. (2014c) and on suggestions received from the Nordic dairy industry and from Nordic breeding companies, our study was designed and conducted to collect new field data from the Swedish RDC population. Therefore, our study is based on entirely new data, and there is no overlap of data between our study and Gustavsson et al. (2014c). The findings of the present study may differ from the study conducted by Gustavsson et al. (2014c), because of distinctive features intrinsic to each study, such as sample size (600 vs. 382 in Gustavsson et al., 2014c), pH adjustment of milk samples, and different model assumptions. In this study, it is important to note that we focused on the relationship of traits in relation to NC milk. For this reason, we discuss only the traits that showed significant results with $\mathrm{NC}$ milk.

\section{Heritability Estimates}

NC Milk. In Swedish RDC, moderate heritability estimate was found for NC milk (Figure 1), and this estimate was lower than the heritability estimated $\left(\mathrm{h}^{2}\right.$ $=0.45$ ) by Gustavsson et al. (2014c). In their statistical model, Gustavsson et al. (2014c) included herd as fixed effect and a genomic relationship matrix based on 382 animals genotyped for 777,000 SNP, whereas our model included herd as a random effect and a genomic relationship matrix based on 600 animals with imputed 50,000 SNP genotypes. Furthermore, the standard error of our heritability for NC milk was $20 \%$ lower than that in Gustavsson et al. (2014c). This means that our estimate is more precise than that of Gustavsson et al. (2014c). Unfortunately, we could not find other studies reporting the heritability of NC milk. However, although Ikonen et al. (2004) did not estimate a heritability for NC milk, their heritability for curd firmness (or gel strength) included NC samples, and was estimated at $\mathrm{h}^{2}=0.26$ with $\mathrm{SE}=0.03$. Our heritability for $\mathrm{G}_{\text {rox }}^{\prime}$ was stronger than that reported in Ikonen et al. (2004), but our estimate was less precise $(\mathrm{SE}=0.10)$. 
Milk Coagulation Properties. For RCT, heritability was moderate for both $\mathrm{RCT}_{\text {rox }}$ and $\mathrm{RCT}_{\text {stress }}$ (Figure 1). However, the standard errors of $\mathrm{RCT}_{\text {rox }}$ and $\mathrm{RCT}_{\text {stress }}$ overlapped, suggesting similar heritability for these traits, despite different definitions of RCT from the 2 rheological systems. It is well established that heritability estimates for RCT differ between breeds (e.g., Cecchinato et al., 2011; Poulsen et al., 2015). In Poulsen et al. (2015), RCT was monitored using free oscillation rheometry, as used in our study. They observed a heritability of RCT of 0.45 for Danish Jersey and 0.28 for Danish Holstein; our heritability estimate for RC$\mathrm{T}_{\text {rox }}$ was within the same range. It is important to note that how RCT is modeled for NC milk samples will affect the heritability of RCT (Cecchinato and Carnier, 2011). We treated NC milk samples as right-censored data when reporting RCT for NC milk samples. This results in higher heritability estimates compared with removing NC milk samples or treating RCT as a binary trait (Cecchinato and Carnier, 2011). For gel strengths, the heritability estimate of $\mathrm{G}^{\prime}$ stress corresponded well with results from Gustavsson et al. $\left(2014 \mathrm{c} ; \mathrm{h}^{2}=0.53\right)$, where the same rheological system and breed were used. Other studies showed variations in the heritability of gel strength (or curd firmness) between 0.11 and 0.43 (e.g., Ikonen et al., 2004; Bonfatti et al., 2011; Costa et al., 2019); our result for $\mathrm{G}_{\text {rox }}^{\prime}$ was within the same range. The heritability estimate of $\sigma_{\mathrm{y} \_ \text {stress }}$ was similar to the estimate by Gustavsson et al. $\left(2014 \mathrm{c}, \mathrm{h}^{2}=0.43\right)$. Our heritability estimate of $\mathrm{CFR}_{\text {rox }}$ was intermediate between the estimates of $\mathrm{CFR}_{\text {rox }}$ reported by Poulsen et al. $(2015)$, with $\mathrm{h}^{2}=0.75$ for Danish Holstein and $\mathrm{h}^{2}=$ 0.15 for Danish Jersey.

Contents of Calcium, $\alpha-L A, \alpha_{S 2}-C N$, and $\kappa-C N$. Despite being nonsignificant, the heritability of calcium content was notably weaker than findings by van Hulzen et al. $\left(2009 ; \mathrm{h}^{2}=0.57\right)$ and Sanchez et al. $\left(2018 ; \mathrm{h}^{2}=0.50\right)$. Calcium content, among other minerals in milk, seems to be influenced by both nongenetic and genetic factors. For calcium content, examples of nongenetic factors are stage of lactation, parity, and feeding (e.g., Tsioulpas et al., 2007; Gaignon et al., 2018), whereas an example of genetic factor is breed (e.g., Buitenhuis et al., 2015). van Hulzen et al. (2009) showed that a large proportion of the total variance for calcium content was explained by additive genetic variance and concluded that calcium content is mostly affected by genetic factors. Furthermore, the heritability of calcium content differed from that of ionic calcium. This difference in heritability estimation could be due to (1) the removal of outliers before estimating heritability for calcium content, (2) the number of samples available for ionic calcium $(\mathrm{n}=354)$, (3) the use of distinct methods of measurements for both traits, or (4) differences in genetic variability between herds.

The heritability estimate of $\alpha$-LA content agreed well with Schopen et al. $\left(2009, \mathrm{~h}^{2}=0.55\right)$ but was higher than the estimates reported by Bonfatti et al. (2011, $\left.\mathrm{h}^{2}=0.11\right)$, Gebreyesus et al. $\left(2016, \mathrm{~h}^{2}=0.22\right)$, Fang et al. $\left(2017, \mathrm{~h}^{2}=0.22\right)$, and Sanchez et al. $\left(2018 ; \mathrm{h}^{2}=\right.$ $0.35)$. We estimated a similar heritability for $\alpha_{\mathrm{S}_{2}} \mathrm{CN}$ compared with estimates by Bonfatti et al. $\left(2011 ; \mathrm{h}^{2}\right.$ $=0.28)$, Fang et al. $\left(2017, \mathrm{~h}^{2}=0.29\right.$ in Montbéliarde cows) and Gebreyesus et al. $\left(2016 ; \mathrm{h}^{2}=0.36\right)$; but low heritability for $\alpha_{\mathrm{S}^{2}} \mathrm{CN}$ compared with estimates by Sanchez et al. $\left(2018 ; h^{2}=0.44\right)$, Schopen et al. $(2009$; $\left.\mathrm{h}^{2}=0.73\right)$ and Fang et al. $\left(2019 ; \mathrm{h}^{2}=0.94\right.$ in Dutch Holstein). Differing heritability estimates between studies may be caused by studying different breeds, sample sizes, or analytical methods. Our estimated heritability of $\kappa$-CN was high but agrees well with Gebreyesus et al. $\left(2016 ; h^{2}=0.79\right)$. Furthermore, heritability of $\kappa-C N$ was notably higher than that reported in other studies, with estimates ranging from 0.37 to 0.64 (Schopen et al., 2009; Bonfatti et al., 2011; Gustavsson et al., 2014c; Fang et al., 2017; Sanchez et al., 2018).

\section{Phenotypic and Genetic Correlations}

NC Milk. Regarding correlations with NC milk, there were major differences between the results of Gustavsson et al. (2014c) and our study. First, Gustavsson et al. (2014c) reported a significant genetic correlation between $\mathrm{NC}$ milk and protein content $\left(r_{g}\right.$ $=0.38$ ). In our study, both genetic and phenotypic correlations were nonsignificant between NC milk and protein content (Table 2), although the directions of the genetic correlations in both studies were the same. Instead, in our study, we found a strong and positive genetic correlation of $\mathrm{NC}$ milk with $\alpha_{\mathrm{S}^{2}} \mathrm{CN}$ content. $\alpha_{\mathrm{S} 2^{-}}$Casein is 1 of the 4 major casein fractions present in milk. This significant and strong genetic correlation is unfavorable, because it means that more $\alpha_{\mathrm{S}_{2}} \mathrm{CN}$ content produced in milk can result in more NC milk. In a study by Jõudu et al. (2008), the effect of $\alpha_{\mathrm{S}_{2}} \mathrm{CN}$ content on coagulation properties was nonsignificant, although Pearson correlations showed that an increase in $\alpha_{\mathrm{S}_{2}} \mathrm{CN}$ content can both improve and worsen coagulation properties, depending on whether $\alpha_{\mathrm{S}_{2}} \mathrm{CN}$ content is expressed as the amount of $\alpha_{\mathrm{S}^{2}} \mathrm{CN}$ or as ratio of $\alpha_{\mathrm{S}_{2}} \mathrm{CN}$ to total CN (Jõudu et al., 2008). We found that an increase in $\alpha_{S 2}$ CN content can worsen milk coagulation properties (Table 2), but this could be because of the inclusion of $\mathrm{NC}$ samples in these correlations. Based on our result and the findings from Jõudu et al. (2008), breeding against NC milk and, thus, in favor of 
a reduced $\alpha_{\mathrm{S}^{2}} \mathrm{CN}$ content, may impair the coagulation ability of the milk samples even more. Second, $\beta$-LG content was genetically $\left(r_{g}=-0.49\right)$ and phenotypically $\left(r_{p}=-0.14\right)$ correlated with NC milk in Gustavsson et al. (2014c). In our study, $\beta$-LG content was only phenotypically correlated with $\mathrm{NC}$ milk. Third, $\kappa-\mathrm{CN}$ content was phenotypically correlated with $\mathrm{NC}$ milk $\left(r_{p}=-0.13\right)$ in Gustavsson et al. (2014c). However, in the present study, $\kappa-\mathrm{CN}$ content was genetically and phenotypically correlated with NC milk. In a breeding program, correlations of $\kappa-\mathrm{CN}$ content with $\mathrm{NC}$ milk suggest that an increase of $\kappa$-CN content in milk can help reduce the prevalence of $\mathrm{NC}$ milk. $\kappa$-Casein is the most important milk protein in the coagulation process, as coagulation is initiated by $\mathrm{\kappa}$-CN hydrolysis (Horne and Lucey, 2017), and a lower $\mathrm{k-CN}$ content has been reported in NC milk previously (Hallén et al., 2010). Therefore, breeding toward increasing the $\mathrm{k}-\mathrm{CN}$ content to reduce $\mathrm{NC}$ milk would most likely benefit overall cheese production. This idea is also supported by the correlations between $\mathrm{k}-\mathrm{CN}$ content and milk coagulation properties. Fourth, phenotypic and genetic correlations between NC milk and milk coagulation properties estimated by Gustavsson et al. (2014c) were weaker than those in our study, likely because of the smaller sample size and the method of analyses. The correlations in Table 2 are most likely not giving a positive-definite matrix. Bending the matrix of correlations to make it positive-definite typically shrinks correlations toward zero. In Gustavsson et al. (2014c), a series of multitrait analysis was done and correlation matrices were positive-definite by design.

The negative correlations between NC milk and calcium content suggest that breeding for a higher calcium content in milk would reduce the frequency of NC milk. A lower calcium content in NC milk agrees with previous studies (Jensen et al., 2012; Gustavsson et al., 2014b), but to our knowledge, our study is the only one to investigate the genetic correlation between calcium content and NC milk. Calcium contributes significantly in the coagulation process by linking the hydrolyzed casein micelles together (Corredig and Salvatore, 2016). Therefore, breeding for an increased amount of calcium in milk should benefit the overall coagulation ability of the milk. This is supported by the significant correlations between calcium content and milk coagulation traits. Nevertheless, breeding cows for increased calcium content in milk might increase the mobilization of calcium in the cows, thus decreasing calcium deposits in the bones. This could weaken the bones and increase milk fever events at parturition of the cow. To a certain extent, these undesirable events could be mitigated by increasing calcium intake by the cow.
Although we could not find any previous reporting of correlations between $\alpha$-LA content and NC milk, previous studies have reported correlations between $\alpha$-LA content and RCT. For example, Bonfatti et al. (2011) showed a genetic correlation of 0.24 , and Ketto et al. (2017) showed a phenotypic correlation of 0.18 between RCT and $\alpha$-LA content. A higher $\alpha$-LA content in NC milk has been reported by Poulsen et al. (2017); however, no correlations were calculated in that study. Our results suggest that an increase of $\alpha$-LA content is phenotypically correlated with a decrease in all milk coagulation property traits and is genetically correlated with decreases in $\mathrm{CFR}_{\text {rox }}$ and $\sigma_{\mathrm{y} \_ \text {stress }}$. The role of whey proteins in milk rennet coagulation is still not fully understood. A recent study on the impact of native whey proteins on milk rennet coagulation showed that a higher ratio of whey proteins to casein could impair coagulation due to physical or steric hindrance (Gamlath et al., 2018). In our study, however, the sum of whey proteins was not significantly correlated with the coagulation traits. On the other hand, Gamlath et al. (2018) did not distinguish between $\alpha$-LA and $\beta$-LG; therefore, an increased amount of whey proteins may also mean an increased amount of $\alpha$-LA. $\alpha$-Lactalbumin is known to have a strong binding site for ionic calcium (Hiraoka et al., 1980; Permyakov and Berliner, 2000), which is an important ion in the rennet coagulation process. We found that NC milk was significantly correlated, both genetically and phenotypically, with lower calcium content and phenotypically correlated with lower ionic calcium. Therefore, the combination of high $\alpha$-LA and low calcium content could be a contributing factor for the inability of the milk to coagulate.

Milk Coagulation Properties. All phenotypic and genetic correlations were strong among milk coagulation properties. In general, genetic correlations were stronger than phenotypic correlations (Table 2). In agreement with previous studies (e.g., Cassandro et al., 2008; Vallas et al., 2010; Gustavsson et al.,2014c), CFR rox was negatively correlated with $\mathrm{RCT}_{\text {rox }}$ and $\mathrm{RCT}_{\text {stress, }}$, which was expected. It is well established that milk coagulation properties are influenced by many factors including breed, among others (Bittante et al., 2012). In Estonian Holstein, Vallas et al. (2010) estimated a lower genetic correlation between curd firmness and RCT $\left(r_{g}=-0.16\right)$ than in the present study. In Brown Swiss, Dadousis et al. (2016) estimated a genetic correlation between RCT and curd firmness $\left(r_{g}=-0.88\right)$ that was in agreement with our study. In Danish Jersey, Poulsen et al. (2015) estimated a nonsignificant genetic correlation between RCT and CFR $\left(r_{g}=0.06\right)$, and in Danish Holstein, their estimated genetic correlation $\left(r_{g}\right.$ $=-0.90)$ was similar to ours. 
Contents of Calcium, $\alpha-L A, \alpha_{S 2}-C N$, and $\kappa-C N$. Contents of calcium, $\alpha-\mathrm{LA}, \alpha_{\mathrm{S}^{2}} \mathrm{CN}$, and $\kappa-\mathrm{CN}$ showed significant genetic correlations with NC milk (Table 2). Calcium content was negatively correlated with NC milk, but was also genetically correlated with higher protein, citric acid, and casein contents. The strongest genetic correlations of calcium content were with protein content and casein content. In Danish Jersey and Holstein cows, Jensen et al. (2012) reported that lower contents of casein and protein have been identified in poorly coagulating and NC milk. Furthermore, Buitenhuis et al. (2015) estimated phenotypic correlations between calcium and protein contents in Danish Holstein $\left(r_{p}=0.95\right)$ and in Danish Jersey $\left(r_{p}=0.93\right)$, and these were stronger than in our study. Although reducing NC milk should benefit the overall coagulation ability, the positive correlations between calcium and contents of protein and casein are also beneficial for cheese production, because higher amounts of protein and casein are known to improve rennet coagulation (Jõudu et al., 2008). A high protein content would also benefit farmers, because protein content is often used to determine milk price in Scandinavian countries and some other European countries.

Unexpected results were the phenotypic and genetic correlations of $\alpha$-LA content with NC milk. Both correlations are unfavorable; that is, working toward increasing the prevalence of NC milk in a context of selective breeding. $\alpha$-Lactalbumin is the second-most-abundant protein in whey. Whey proteins are widely used in a variety of different products because of their nutritional properties (Lucey, 2009). Additionally, $\alpha$-LA content was positively correlated with $\alpha_{S_{2}} \mathrm{CN}$ as well as whey protein contents. Although the direction of the genetic correlations was the same, our genetic correlation between $\alpha-\mathrm{LA}$ and $\alpha_{\mathrm{S}^{-}} \mathrm{CN}$ contents was stronger than that reported by Bonfatti et al. (2011) and Gebreyesus et al. (2016). However, our genetic correlation between $\alpha-\mathrm{LA}$ and whey protein contents was weaker than that reported by Bonfatti et al. (2011). Furthermore, $\alpha$-LA content was negatively correlated with contents of fat, protein, casein, $\beta-\mathrm{LG}, \kappa-\mathrm{CN}$, citric acid, $\beta-\mathrm{CN}$, and sum of $\mathrm{CN}$. The genetic correlations between $\alpha$-LA and fat content, protein content, $\beta-\mathrm{LG}$, and $\kappa$-CN were in agreement with Schopen et al. (2009), whereas genetic correlations between $\alpha-\mathrm{LA}$ and $\beta-\mathrm{CN}$ and sum of $\mathrm{CN}$ were in the opposite direction to estimations by Schopen et al. (2009). Also in the opposite direction were the correlations estimated by Gebreyesus et al. (2016) between $\alpha-\mathrm{LA}$ and $\beta-\mathrm{CN}, \kappa-\mathrm{CN}$, and $\beta$-LG. Based on our results, although a lower content of $\alpha$-LA could reduce the frequency of NC milk, it would simultaneously increase fat content and reduce $\alpha_{\mathrm{S}^{2}} \mathrm{CN}$ content in milk. An increased fat content in milk is beneficial, not only for cheese production but for various dairy applications, and fat content is often used to determine milk price in Scandinavian and other European countries, similar to protein content. However, it should be mentioned that the individual proteins were expressed as percentage of total protein; therefore, the sum of these individual proteins sum to 1 in each milk sample, which tends to generate negative covariances with main components such as casein and whey proteins.

$\kappa$-Casein content showed a negative genetic correlation with NC milk and, further, with casein micelle size, sum of whey proteins, and contents of $\alpha_{\mathrm{S} 1}-\mathrm{CN}$ and $\alpha_{S 2}-\mathrm{CN}$ (Table 2). These results are in agreement with: (a) Schopen et al. (2009) and Bonfatti et al. (2011) for sum of whey proteins; (b) Schopen et al. (2009), Bonfatti et al. (2011), and Gebreyesus et al. (2016) for $\alpha_{\mathrm{S}_{1}} \mathrm{CN}$ content; and (c) Bonfatti et al. (2011) and Gebreyesus et al. (2016) for $\alpha_{S_{2}-} \mathrm{CN}$ content. Furthermore, our study found a positive phenotypic correlation of $\kappa-\mathrm{CN}$ content with the sum of $\mathrm{CN}$, which is in agreement with Schopen et al. (2009). Although not found in genetic studies, some studies have reported a negative Pearson correlation between $\kappa-\mathrm{CN}$ content with casein micelle size (e.g., Davies and Law, 1983; Dalgleish et al., 1989). From the observation that $\mathrm{k}-\mathrm{CN}$ is more abundant in small micelles, $\kappa$-CN was suggested to prohibit the growth of casein micelles (e.g., Dalgleish et al., 1989). A small casein micelle size has been shown to be beneficial for rennet coagulation (Glantz et al., 2010), whereby the negative correlation between $\kappa-\mathrm{CN}$ content and casein micelle size is beneficial from a breeding perspective.

Finally, $\alpha_{\mathrm{S}_{2}} \mathrm{CN}$ content showed a positive correlation with NC milk, as well as genetic correlations with protein and casein contents (Table 2). This means that less $\alpha_{\mathrm{S}_{2}} \mathrm{CN}$ will result in less $\mathrm{NC}$ milk and, thereby, more protein and casein in milk. The correlation between contents of $\alpha_{\mathrm{S}_{2}} \mathrm{CN}$ and protein agrees with Sanchez et al. (2017) for French Holstein and for Normande breeds, but disagrees with Schopen et al. (2009) for Dutch Holsteins.

\section{Breeding Perspectives of NC Milk}

Breeding against $\mathrm{NC}$ milk has already been suggested (e.g., Tyrisevä et al., 2004; Gustavsson et al., 2014c), because genetic factors seem to have a role in the occurrence of NC milk. Noncoagulating milk is a complex trait, and both genetic and environmental factors are likely involved in its occurrence. Genetic factors include breed, bulls, and breeding strategies, and we know now that $\mathrm{NC}$ milk is present in several RDC populations through exchanges of semen (personal communication with H. Stålhammar, Viking Genetics, Skara, Sweden). 
Because breeding strategies may be a part of the solution, research to reduce the occurrence of $\mathrm{NC}$ milk in animal breeding has mainly focused on (1) identifying chromosomal regions by scrutinizing the bovine genome; and (2) finding traits that are not routinely recorded to potentially include them in the breeding goal. On the first front, studies by Tyrisevä et al. (2008) and Duchemin et al. (2016) showed that regions of a few chromosomes are associated with $\mathrm{NC}$ milk. On the second, Gustavsson et al. (2014c) hypothesized that artificially selecting cows for high protein content will increase the occurrence of NC milk. This hypothesis was supported by the genetic correlation found between NC milk and protein content in their study. From our results, we found significant genetic correlations of $\mathrm{NC}$ milk with contents of $\alpha_{S_{2}}$ CN and $\alpha$-LA, which indirectly supports the hypothesis from Gustavsson et al. (2014c), but we found no direct correlation with total protein. These 2 genetic correlations work in favor of increasing the frequency of $\mathrm{NC}$ milk. Interestingly, for most of the studied traits, the genetic correlations of $\alpha_{\mathrm{S} 2}$-CN content behaved in the opposite direction to $\kappa$-CN content (Table 2). Another interesting trait is content of calcium, for which a strong negative genetic correlation has been found with NC milk. Because contents of $\alpha_{\mathrm{S} 2^{-}} \mathrm{CN}, \kappa-\mathrm{CN}$, and calcium strongly correlate with all milk coagulation properties, we suggest that content of either $\alpha_{\mathrm{S}_{2}} \mathrm{CN}, \kappa-\mathrm{CN}$, or calcium could be used as indicator traits for the occurrence of NC milk. Although contents of $\kappa-\mathrm{CN}$ and calcium showed stronger genetic correlations than did content of $\alpha_{\mathrm{S}_{2}} \mathrm{CN}$, contents of $\kappa-\mathrm{CN}$ and calcium did not correlate with contents of protein, casein, and $\alpha-\mathrm{LA}$ as did contents of $\alpha_{\mathrm{S}^{-}} \mathrm{CN}$. Nevertheless, $\kappa-\mathrm{CN}$ content had a higher estimated heritability than $\alpha_{\mathrm{S}^{-}} \mathrm{CN}$ content and calcium content.

Moreover, we suggest that breeding programs should be aimed toward traits with genetic correlations to $\mathrm{NC}$ milk, to reduce its frequency in Swedish RDC. However, it is important to consider how these breeding goals would alter the composition of milk. Furthermore, it would be difficult to predict how milk composition would change because of (1) existing genetic correlations between all the studied traits, and (2) aspects not considered in this study, such as the effects of milk protein variants. Based on our findings, for example, reducing the content of $\alpha_{\mathrm{S}^{2}} \mathrm{CN}$ in milk, would (1) reduce the content of $\alpha-\mathrm{LA}$; and (2) increase the contents of protein, casein, and $\kappa-\mathrm{CN}$ and improve all milk coagulation properties. Furthermore, reducing the content of $\alpha-\mathrm{LA}$ would reduce the content of $\alpha_{\mathrm{S1}}-\mathrm{CN}$, and increase the contents of fat, casein, $\beta-\mathrm{LG}$, and $\kappa-\mathrm{CN}$, and improve $\sigma_{y_{\_} \text {stress }}$. Consequently, this may result in changed milk composition that, in turn, may affect the physical and organoleptic properties of milk.

To measure the content of different proteins in milk using LC-HRMS, as we did in this study, can be time consuming. It has also been suggested that protein composition can be predicted using mid-infrared spectrometry, with an accuracy of 0.59 for $\alpha$-LA, 0.80 for $\kappa-C N$, and 0.82 for $\alpha_{S_{2}}$ CN contents (Sanchez et al., 2018). Using either LC-HRMS or mid-infrared spectrometry would mean that selecting for a specific protein in the milk may be faster and cheaper than using rheological parameters for selection.

In summary, we showed that variation is present in $\mathrm{NC}$ milk, part of which is influenced by genetic factors. The modest heritability of NC milk suggests that selective breeding can be used to reduce its prevalence. In this study, phenotypic and genetic correlations with $\mathrm{NC}$ milk suggest that many correlations between traits exist, making it difficult to predict the real consequences on the composition of milk if selective breeding is applied. We speculate that some of these consequences may lead to changes in the composition of milk, most likely affecting its physical and organoleptic properties. However, our results support the creation of an indicator trait to predict the occurrence of $\mathrm{NC}$ milk at herd level, and this trait is $\kappa-\mathrm{CN}$.

\section{ACKNOWLEDGMENTS}

The authors thank Tomas Sandin (Växa Sverige, Sweden) for collecting the milk and blood samples. We also thank Chr. Hansen A/S (Denmark) for kindly gifting Chy-Max Plus to the study and to Nordic Cattle Genetic Evaluation (NAV, Sweden) for providing the imputed 50K data. Finally, this study was funded by the Swedish Farmers' Foundation of Agricultural Research, Sweden (grant number O-15-20-274) and VikingGenetics, Denmark. The authors have not stated any conflicts of interest.

\section{REFERENCES}

Bittante, G., M. Penasa, and A. Cecchinato. 2012. Invited review: Genetics and modeling of milk coagulation properties. J. Dairy Sci. 95:6843-6870. https://doi.org/10.3168/jds.2012-5507.

Bonfatti, V., A. Cecchinato, L. Gallo, A. Blasco, and P. Carnier. 2011. Genetic analysis of detailed milk protein composition and coagulation properties in Simmental cattle. J. Dairy Sci. 94:5183-5193. https://doi.org/10.3168/jds.2011-4297.

Buitenhuis, A. J., U. K. Sundekilde, N. A. Poulsen, H. C. Bertram, L. B. Larsen, and P. Sørensen. 2013. Estimation of genetic parameters and detection of quantitative trait loci for metabolites in Danish Holstein milk. J. Dairy Sci. 96:3285-3295. https://doi.org/ 10.3168/jds.2012-5914.

Buitenhuis, B., N. A. Poulsen, L. B. Larsen, and J. Sehested. 2015. Estimation of genetic parameters and detection of quantitative trait 
loci for minerals in Danish Holstein and Danish Jersey milk. BMC Genet. 16:52. https://doi.org/10.1186/s12863-015-0209-9.

Cassandro, M., A. Comin, M. Ojala, R. Dal Zotto, M. De Marchi, L. Gallo, P. Carnier, and G. Bittante. 2008. Genetic parameters of milk coagulation properties and their relationships with milk yield and quality traits in Italian Holstein cows. J. Dairy Sci. 91:371376. https://doi.org/10.3168/jds.2007-0308.

Cecchinato, A., and P. Carnier. 2011. Short communication: Statistical models for the analysis of coagulation traits using coagulating and noncoagulating milk information. J. Dairy Sci. 94:4214-4219. https://doi.org/10.3168/jds.2010-3911.

Cecchinato, A., M. Penasa, M. De Marchi, L. Gallo, G. Bittante, and P. Carnier. 2011. Genetic parameters of coagulation properties, milk yield, quality, and acidity estimated using coagulating and noncoagulating milk information in Brown Swiss and HolsteinFriesian cows. J. Dairy Sci. 94:4205-4213. https://doi.org/10 $.3168 /$ jds.2010-3913.

Corredig, M., and E. Salvatore. 2016. Enzymatic coagulation of milk. Pages 287-308 in Advanced Dairy Chemistry: Volume 1B: Proteins: Applied Aspects. 4th ed. P. L. H. McSweeney and J. A. O'Mahony, ed. Springer, New York, NY.

Costa, A., G. Visentin, M. De Marchi, M. Cassandro, and M. Penasa. 2019. Genetic relationships of lactose and freezing point with minerals and coagulation traits predicted from milk mid-infrared spectra in Holstein cows. J. Dairy Sci. 102:7217-7225. https://doi .org/10.3168/jds.2018-15378.

Dadousis, C., S. Biffani, C. Cipolat-Gotet, E. L. Nicolazzi, A. Rossoni, E. Santus, G. Bittante, and A. Cecchinato. 2016. Genome-wide association of coagulation properties, curd firmness modeling, protein percentage, and acidity in milk from Brown Swiss cows. J. Dairy Sci. 99:3654-3666. https://doi.org/10.3168/jds.2015-10078.

Dalgleish, D. G., D. S. Horne, and A. J. R. Law. 1989. Size-related differences in bovine casein micelles. Biochim. Biophys. Acta 991:383-387. https://doi.org/10.1016/0304-4165(89)90061-5.

Davies, D. T., and A. J. R. Law. 1983. Variation in the protein composition of bovine casein micelles and serum casein in relation to micellar size and milk temperature. J. Dairy Res. 50:67-75. https: //doi.org/10.1017/S0022029900032532.

Duchemin, S. I., M. Glantz, D. J. de Koning, M. Paulsson, and W. F. Fikse. 2016. Identification of QTL on chromosome 18 associated with non-coagulating milk in Swedish Red cows. Front. Genet. 7:57. https://doi.org/10.3389/fgene.2016.00057.

Fang, Z. H., H. Bovenhuis, A. Delacroix-Buchet, G. Miranda, D. Boichard, M. H. P. W. Visker, and P. Martin. 2017. Genetic and nongenetic factors contributing to differences in $\alpha$ S-casein phosphorylation isoforms and other major milk proteins. J. Dairy Sci. 100:5564-5577. https://doi.org/10.3168/jds.2016-12338.

Fang, Z. H., H. Bovenhuis, H. J. F. van Valenberg, P. Martin, S. I. Duchemin, T. Huppertz, and M. H. P. W. Visker. 2019. Genomewide association study for $\alpha_{S^{-}}$and $\alpha_{S 2^{2}}$ casein phosphorylation in Dutch Holstein Friesian. J. Dairy Sci. 102:1374-1385. https://doi .org/10.3168/jds.2018-15593.

Gaignon, P., M. Gelé, C. Hurtaud, and A. Boudon. 2018. Characterization of the nongenetic causes of variation in the calcium content of bovine milk on French farms. J. Dairy Sci. 101:4554-4569. https: //doi.org/10.3168/jds.2017-14043.

Gamlath, C. J., T. S. H. Leong, M. Ashokkumar, and G. J. O. Martin. 2018. The inhibitory roles of native whey protein on the rennet gelation of bovine milk. Food Chem. 244:36-43. https://doi.org/ 10.1016/j.foodchem.2017.10.029.

Gebreyesus, G., M. S. Lund, L. Janss, N. A. Poulsen, L. B. Larsen, H. Bovenhuis, and A. J. Buitenhuis. 2016. Multi-trait estimation of genetic parameters for milk protein composition in the Danish Holstein. J. Dairy Sci. 99:2863-2866. https://doi.org/10.3168/jds .2015-10501.

Gilmour, A. R., B. J. Gogel, B. R. Cullis, S. Welham, and R. Thompson. 2015. ASReml user guide release 4.1 structural specification. VSN International Ltd., Hemel Hempstead, UK.

Glantz, M., T. G. Devold, G. E. Vegarud, H. Lindmark-Månsson, H. Stålhammar, and M. Paulsson. 2010. Importance of casein micelle size and milk composition for milk gelation. J. Dairy Sci. 93:14441451. https://doi.org/10.3168/jds.2009-2856.

Gustavsson, F., A. J. Buitenhuis, M. Johansson, H. P. Bertelsen, M. Glantz, N. A. Poulsen, H. Lindmark Månsson, H. Stålhammar, L. B. Larsen, C. Bendixen, M. Paulsson, and A. Andrén. 2014a. Effects of breed and casein genetic variants on protein profile in milk from Swedish Red, Danish Holstein, and Danish Jersey cows. J. Dairy Sci. 97:3866-3877. https://doi.org/10.3168/jds.2013-7312.

Gustavsson, F., M. Glantz, A. J. Buitenhuis, H. Lindmark Månsson, H. Stålhammar, A. Andrén, and M. Paulsson. 2014b. Factors influencing chymosin-induced gelation of milk from individual dairy cows: Major effects of casein micelle size and calcium. Int. Dairy J. 39:201-208. https://doi.org/10.1016/j.idairyj.2014.06.011.

Gustavsson, F., M. Glantz, N. A. Poulsen, L. Wadsö, H. Stålhammar, A. Andrén, H. Lindmark-Månsson, L. B. Larsen, M. Paulsson, and W. F. Fikse. 2014c. Genetic parameters for rennet- and acidinduced coagulation properties in milk from Swedish Red dairy cows. J. Dairy Sci. 97:5219-5229. https://doi.org/10.3168/jds.2014 $-7996$.

Hallén, E., A. Lundén, A.-M. Tyrisevä, M. Westerlind, and A. Andrén. 2010. Composition of poorly and non-coagulating bovine milk and effect of calcium addition. J. Dairy Res. 77:398-403. https://doi .org/10.1017/S0022029910000671.

Hallén, E., A. Wedholm, A. Andrén, and A. Lundén. 2008. Effect of beta-casein, kappa-casein and beta-lactoglobulin genotypes on concentration of milk protein variants. J. Anim. Breed. Genet. 125:119-129. https://doi.org/10.1111/j.1439-0388.2007.00706.x.

Hiraoka, Y., T. Segawa, K. Kuwajima, S. Sugai, and N. Murai. 1980. $\alpha$-Lactalbumin: A calcium metalloprotein. Biochem. Biophys. Res. Commun. 95:1098-1104. https://doi.org/10.1016/0006 -291X(80)91585-5.

Horne, D. S., and J. A. Lucey. 2017. Cheese: Rennet-induced coagulation of milk. 4th ed. P. L. H. McSweeney, P. F. Fox, P. D. Cotter, and D. W. Everett, ed. Elsevier Ltd., New York, NY.

Ikonen, T., S. Morri, A.-M. Tyrisevä, O. Ruottinen, and M. Ojala. 2004. Genetic and phenotypic correlations between milk coagulation properties, milk production traits, somatic cell count, casein content, and pH of milk. J. Dairy Sci. 87:458-467. https://doi.org/ 10.3168/jds.S0022-0302(04)73185-9.

Jensen, H. B., N. A. Poulsen, K. K. Andersen, M. Hammershøj, H. D. Poulsen, and L. B. Larsen. 2012. Distinct composition of bovine milk from Jersey and Holstein-Friesian cows with good, poor, or noncoagulation properties as reflected in protein genetic variants and isoforms. J. Dairy Sci. 95:6905-6917. https://doi.org/10.3168/ jds.2012-5675.

Jõudu, I., M. Henno, T. Kaart, T. Püssa, and O. Kärt. 2008. The effect of milk protein contents on the rennet coagulation properties of milk from individual dairy cows. Int. Dairy J. 18:964-967. https: //doi.org/10.1016/j.idairyj.2008.02.002.

Ketto, I. A., T. M. Knutsen, J. Øyaas, B. Heringstad, T. Ådnøy, T. Guldbrandsen Devold, and S. B. Skeie. 2017. Effects of milk protein polymorphism and composition, casein micelle size and salt distribution on the milk coagulation properties in Norwegian Red cattle. Int. Dairy J. 70:55-64. https://doi.org/10.1016/j.idairyj .2016.10.010.

Lucey, J. A. 2009. Milk protein gels. Pages 449-471 in Milk ProteinsFrom Expression to Food. Vol. 1. A. Thompson, M. Boland and H. Singh, ed. Elsevier Inc., Burlington, MA.

Nilsson, K., H. Stålhammar, M. Stenholdt Hansen, H. LindmarkMånsson, S. I. Duchemin, W. F. Fikse, D. J. de Koning, M. Paulsson, and M. Glantz. 2019. Characterization of non-coagulating milk and effects of milk composition and physical properties on rennet-induced coagulation in Swedish Red Dairy Cattle. Int Dairy J. 95:50-57. https://doi.org/10.1016/j.idairyj.2019.03.006.

Okigbo, L. M., G. H. Richardson, R. J. Brown, and C. A. Ernstrom. 1985. Variation in coagulation properties of milk from individual cows. J. Dairy Sci. 68:822-828. https://doi.org/10.3168/jds.S0022 $-0302(85) 80899-7$.

Permyakov, E. A., and L. J. Berliner. 2000. $\alpha$-Lactalbumin: Structure and function. FEBS Lett. 473:269-274. https://doi.org/10.1016/ S0014-5793(00)01546-5. 
Poulsen, N. A., A. J. Buitenhuis, and L. B. Larsen. 2015. Phenotypic and genetic associations of milk traits with milk coagulation properties. J. Dairy Sci. 98:2079-2087. https://doi.org/10.3168/ jds.2014-7944.

Poulsen, N. A., V. R. Gregersen, G. M. Maciel, L. B. Madsen, B. Buitenhuis, M. S. Hansen, C. Bendixen, and L. B. Larsen. 2017. Novel genetic variation associated to CSN3 strongly affects rennetinduced milk coagulation. Int. Dairy J. 71:122-130. https://doi .org/10.1016/j.idairyj.2017.03.012.

Rauh, V. M., L. B. Johansen, M. Bakman, R. Ipsen, M. Paulsson, L. B. Larsen, and M. Hammershøj. 2015. Protein lactosylation in UHT milk during storage measured by Liquid Chromatography - Mass Spectrometry and quantification of furosine. Int. J. Dairy Technol. 68:486-494. https://doi.org/10.1111/1471-0307.12265.

Sanchez, M. P., M. El Jabri, S. Minéry, V. Wolf, E. Beuvier, C. Laithier, A. Delacroix-Buchet, M. Brochard, and D. Boichard. 2018. Genetic parameters for cheese-making properties and milk composition predicted from mid-infrared spectra in a large data set of Montbéliarde cows. J. Dairy Sci. 101:10048-10061. https://doi .org/10.3168/jds.2018-14878.

Sanchez, M. P., M. Ferrand, M. Gelé, D. Pourchet, G. Miranda, P. Martin, M. Brochard, and D. Boichard. 2017. Short communication: Genetic parameters for milk protein composition predicted using mid-infrared spectroscopy in the French Montbéliarde, Normande, and Holstein dairy cattle breeds. J. Dairy Sci. 100:63716375. https://doi.org/10.3168/jds.2017-12663.

Sargolzaei, M., J. P. Chesnais, and F. S. Schenkel. 2014. A new approach for efficient genotype imputation using information from relatives. BMC Genomics 15:478. https://doi.org/10.1186/1471 $-2164-15-478$.

Schopen, G. C. B., J. M. L. Heck, H. Bovenhuis, M. H. P. W. Visker, H. J. F. Van Valenberg, and J. A. M. Van Arendonk. 2009. Genetic parameters for major milk proteins in Dutch Holstein-Friesians. J. Dairy Sci. 92:1182-1191. https://doi.org/10.3168/jds.2008-1281.

Tervala, H.-L., V. Antila, J. Syväjärvi, and U. B. Lindström. 1983. Variations in the renneting properties of milk. Meijeritieteellinen Aikakauskirja XLI 2:24-33.
Tsioulpas, A., M. J. Lewis, and A. S. Grandison. 2007. Effect of minerals on casein micelle stability of cows' milk. J. Dairy Res. 74:167173. https://doi.org/10.1017/S0022029906002330.

Tyrisevä, A.-M., K. Elo, A. Kuusipuro, V. Vilva, I. Jänönen, H. Karjalainen, T. Ikonen, and M. Ojala. 2008. Chromosomal regions underlying noncoagulation of milk in Finnish Ayrshire cows. Genetics 180:1211-1220. https://doi.org/10.1534/genetics.107.083964.

Tyrisevä, A.-M., T. Vahlsten, O. Ruottinen, and M. Ojala. 2004 Noncoagulation of milk in Finnish Ayrshire and Holstein-Friesian cows and effect of herds on milk coagulation ability. J. Dairy Sci. 87:3958-3966. https://doi.org/10.3168/jds.S0022-0302(04)73536 $-5$.

Vallas, M., H. Bovenhuis, T. Kaart, K. Pärna, H. Kiiman, and E. Pärna. 2010. Genetic parameters for milk coagulation properties in Estonian Holstein cows. J. Dairy Sci. 93:3789-3796. https://doi .org $/ 10.3168 /$ jds.2009-2435.

van Hulzen, K. J. E., R. C. Sprong, R. van der Meer, and J. A. M. van Arendonk. 2009. Genetic and nongenetic variation in concentration of selenium, calcium, potassium, zinc, magnesium, and phosphorus in milk of Dutch Holstein-Friesian cows. J. Dairy Sci. 92:5754-5759. https://doi.org/10.3168/jds.2009-2406.

VanRaden, P. M. 2008. Efficient methods to compute genomic predictions. J. Dairy Sci. 91:4414-4423. https://doi.org/10.3168/jds .2007-0980.

Wilmink, J. B. M. 1987. Adjustment of test-day milk, fat and protein yield for age, season and stage of lactation. Livest. Prod. Sci. 16:335-348. https://doi.org/10.1016/0301-6226(87)90003-0.

Zimin, A. V., A. L. Delcher, L. Florea, D. R. Kelley, M. C. Schatz, D. Puiu, F. Hanrahan, G. Pertea, C. P. Van Tassell, T. S. Sonstegard, G. Marçais, M. Roberts, P. Subramanian, J. A. Yorke, and S. L. Salzberg. 2009. A whole-genome assembly of the domestic cow, Bos taurus. Genome Biol. 10:R42. https://doi.org/10.1186/ gb-2009-10-4-r42 